Social Work/Maatskaplike Werk Vol 56 No 3; Issue 8

http://socialwork.journals.ac.za/pub

doi:http://dx.doi.org/10.15270/56-3-862

FAMILY CONNECTEDNESS IN FAMILIES DEALING WITH ADOLESCENTS IN CONFLICT WITH THE LAW

Merle Heather Danhouse, Charlene Erasmus

This article explored family connectedness and the way that families are dealing with adolescents in conflict with the law. Ten adolescents, ten family members, and five social workers constituted the sample for the study. Data collection was done through semi-structured interviews. Three themes were identified through thematic analysis. The results of this study clearly show that the level of connectedness amongst families influences how they deal with adolescents in conflict with the law. Family structure and parental engagement were key factors affecting the relationship with the adolescent. A low level of connectedness was evident in all the families interviewed.

Ms Merle Heather Danhouse, Masters Student, University of the Western Cape, Cape Town, South Africa.

Dr Charlene J Erasmus, University of the Western Cape, Cape Town, South Africa.

Merle Heather Danhouse, ORCiD: 0000-0001-8851-436

Charlene J Erasmus, ORCiD: 0000-0002-1404-7294

8530107@myuwc.ac.za

cjerasmus@uwc.ac.za

Keywords: adolescents in conflict with the law, connectedness, delinquent behaviour, family connectedness, family functioning, general systems theory 


\title{
FAMILY CONNECTEDNESS IN FAMILIES DEALING WITH ADOLESCENTS IN CONFLICT WITH THE LAW
}

\author{
Merle Heather Danhouse, Charlene J Erasmus \\ Ms Merle Heather Danhouse, Masters Student, University of the Western Cape, Cape Town, South \\ Africa. \\ Dr Charlene J Erasmus, University of the Western Cape, Cape Town, South Africa.
}

Merle Heather Danhouse, ORCiD: 0000-0001-8851-436

Charlene J Erasmus, ORCiD: 0000-0002-1404-7294

\section{INTRODUCTION AND PROBLEM STATEMENT}

South Africa has recognized in its legislative processes the importance of family as the strongest form of connection with the adolescent in the rendering of support and protection. In addressing the high rate of adolescent conflicts with the law, the Republic of South Africa, Child Justice Act (Act No 75 of 2008) was implemented. The purpose of this Act is to restore and rehabilitate adolescents manifesting deviant behaviour within the context of family and community (Clark, 2010). This aim was reiterated by the Family Policy of the Department of Social Development (DSD) (2013a) in South Africa and reinforced the vital need of family for adolescent wellbeing and positive development (Hall, Richter, Mokomane \& Lake, 2018; Makiwane \& Berry, 2013). It is thus evident that the connectedness that family members have with one another could be used as an effective tool in purposefully addressing behavioural challenges in the adolescent. Therefore, love, warmth, security and support are primary concepts in defining family connectedness (Barber \& Schluterman, 2008; Chen, Brody \& Miller, 2017; Ward, Makusha, \& Bray, 2015). Relevant to the South African context and highlighting the importance of family, Haghdoost, Abazari, Abbaszadeh and Rabori (2014) in their research conducted amongst high school students in Kerman found that family closeness, the level of education of the father and the religious beliefs of families are significant protective factors that help prevent risky adolescent behaviours. A study conducted in Alexandria focusing on the parent-adolescent relationship found that it has an influence on the sexual behaviour of the adolescent (Shehata \& Ramadan, 2010). Additional studies by Ponappa, Bartle-Haring and Day (2014) and Noble-Carr, Barker, McArthur and Woodman (2014) identified family closeness as being central to the development of the adolescent's personality and degree of involvement in risky behaviour. It is thus evident that parental closeness with the adolescent is a key element in the adolescent's development and behaviour patterns.

Adolescence is a formative stage of development. During this phase adolescents seek to develop autonomy and their own identity (Rawatlal, Pillay \& Kliewer, 2015). Throughout this phase they experience a range of conflicts and tend to challenge family and societal norms. These behaviours expose them to situations such as stealing, excessive drinking, assaulting a person, or shoplifting (UNICEF, 2008), which then leads to conflicts with the law. These challenging behaviours are criminal in nature and occur worldwide, not bound to a specific race or culture (Sukyirun, 2016; Weng, Ran \& Chui, 2016). Boys are more prone to externalising problem behaviours such as fighting or disagreements, whereas girls tend to internalise their behaviour and withdraw from the family (Laizane, 2012). Furthermore, adolescents struggle with their own identity and harbour feelings of anxiety, anger and fear, which becomes problematic to cope with making them less emotionally available to their family (Haghdoost et al., 2014). Consequently, adolescents who experience emotional turmoil often exhibit behavioural problems and then come into conflict with the law, either through being arrested or suspected of having committed a crime (Skrzypiec, 2013).

Several researchers have pointed out that adolescents are often challenged by their family composition, leading to their withdrawal from family relationships and their subsequent engagement in risky 
behaviours (; Department of Social Development (DSD), 2013a; Schermerhorn, Chow \& Cummings, 2010). The South African Child Gauge focuses on family in relation to the state. The latest edition shows that 6,1 million $(37,9 \%)$ households in South Africa are headed by women. This means that in these households women are solely responsible for the care of their children (Hall et al., 2018; Statistics South Africa, 2012). Only 50\% of these children have daily contact with a biological father and $36 \%$ of families have to live with their extended families ( Department of Social Development, 2013b); Holborn \& Eddy, 2011; Hui, Molden \& Finkel, 2013). Single parents experience immense pressure, especially because they have to fulfil a dual parenting role, work irregular or long hours, while simultaneously maintaining a stable relationship with their adolescent child (Han, Miller \& Waldfogel, 2010; Ponappa et al., 2014). Furthermore, single parenting and the low educational level of parents have an influence on the adolescent's education and well-being (Ellis \& Adams, 2009). It is evident that the family composition provides the environment for the building of connectedness. Therefore, if significant members are absent or not present in the lives of their children, it could lead to the children's involvement in risky behaviour. Similarly, Noble-Carr et al., (2014) found in their participatory qualitative study that connectedness with family, especially with their parents, is essential for adolescent wellbeing.

Families in South Africa are exposed to poverty, substance abuse and breakdown in parental relationships, which relates to divorce and single parenting (Department of Social Development, 2013a; Makiwane \& Berry, 2013). In 2011, 27,3\% of marriages within the African, Coloured and Indian communities lasted only five to nine years before ending in divorce (Department of Social Development, 2013a). This consequently leads to dysfunctionality in households. Marital breakdown leads to a breakdown in communication between marital partners as well as with their children, impacting on their interpersonal relationships and their ability to manage conflict in a balanced way (Hadžikapetanovic, Babic \& Bjelošvic, 2017). Parents who are in constant conflict create environments that are harsh and hostile, exacerbating the deviant behaviour of the adolescent. Parental tension, conflict and disagreements result in adolescents withdrawing from their parents and becoming more involved in delinquent behaviour (Shehata \& Ramadan, 2010). Unresolved tensions in these dysfunctional households increase when their difficult situation is further compounded by the experience of poverty and a lack of parental love and affection (Holborn \& Eddy, 2011; Makiwane \& Berry, 2013; Riggs, 2013). Evident from the above discussion is that the quality of family interaction influences child and family outcomes which, if dysfunctional, could lead to family disintegration and adolescents' withdrawal from family interactions (Moore, Kinghorn, \& Bandy, 2011).

Another factor that contributes to adolescents coming into conflict with the law and withdrawing from their family is financial deprivation. This factor puts them at risk of health-related and behavioural problems, as well as low academic performance. In addition, the lack of financial resources also means that these parents lack the ability to provide for the adolescents' material and psychological needs (Shanks \& Danziger, 2011). Furthermore, the high rate of substance abuse in South African families impacts detrimentally on the independence, care and support of adolescents, as parents are unable to consistently monitor their children or develop strong cohesive relationships (Muusha, 2012). Such families manifest depression, violent behaviour and various forms of crime, with adolescents lacking parental affirmation and communication. In addition, the adolescents are left unmonitored, with no visible measures of control in place, rendering these families dysfunctional (Jesuraj, 2012). Adolescents living in dysfunctional families tend to experience feelings of abandonment, anxiety, fear, anger, concern, embarrassment and/or guilt, which lead to problem behaviours (Haghdoost et al., 2014). Families with dysfunctional relationships have a limited understanding of the adolescents' need for comfort, security and exploration, affecting their closeness and increasing their risk of engaging in substance abuse (Hummel, Shelton, Heron, Moore \& Bree, 2013).

Consequently, the quality of the connectedness that family members have with one another has an influence on the parenting style and practices of the parent. This is particularly so for parents who have 
limited resources and have to fulfil dual parenting roles, for example, the single parent will show inconsistencies in their parenting style (Baker \& Mutchler, 2010). Inconsistencies within these households arise when the parent has to work irregular hours, is not able to monitor or discipline their children in a consistent manner, or suffers from exhaustion and is therefore emotionally unavailable to the adolescent. These inconsistencies contribute to parental neglect, limited engagement, and a breakdown in the quality of the relationship with the adolescent. A poor reciprocal relationship between the parent and the adolescent leads to unhappiness, with adolescents not adhering to family rules and being exposed to negative friendships on the streets. In addition, the adolescent disconnects from school and becomes an early school dropout, expresses him/herself through risky sexual behaviour, associates with negative friends, and engages in delinquent behaviour. It could be said that the adolescent's behaviour and the parenting practices of the parent either strengthen or weaken the parentadolescent relationship, which in turn determines the quality of family connectedness and the adolescent's defiance of family norms. Parent adolescent connectedness is thus crucial for the positive development of the adolescent, his/her presence in the household, and a sense of belonging. Therefore, if the adolescent feels less connected, they become vulnerable to defying the norms of society and become in conflict with the law.

Parents that have no or limited connection with the adolescent lack the necessary coping mechanisms to deal with the adolescent who is in conflict with the law. Dysfunctionality between subsystems and within the subsystem impacts on communication and the response to the behaviour of the adolescent (Syce, 2016). Most of these parents become overtly involved in controlling the behaviour of the adolescent, leaving them with limited opportunity to make choices about their own behaviour. They also become harsh and punitive in their discipline, which impacts on the communication and interaction with the adolescent. This means that parenting practices are adapted or changed to achieve equilibrium within the family (Goldweber, Dmitrieva, Cauffman, Piquero \& Steinberg, 2011).

International research regarding family connectedness has been conducted highlighting family connectedness and the risky behaviour of adolescents (Haghdoost et al., 2014), parental closeness (Cavendish, Montague, Enders \& Dietz, 2014; Ponappa, Bartle-Haring \& Day, 2014), character development and a sense of belonging (Noble-Carr, Barker, McArthur \& Woodman, 2014) and the working hours of parents (Han, Miller \& Wildfogel, 2010). In South Africa limited research has been done regarding family connectedness and on families dealing with adolescents in conflict with the law. Local research has focused mainly on connectedness to school (Schulze \& Naidu, 2014) and spending leisure time with family (Wittenberg, 2009; Rawatlal \& Petersen, 2012; Schulze \& Naidu, 2014). Therefore, this study aimed to fill this gap by exploring family connectedness as a link to dealing with adolescents in conflict with the law within the South African context, and thereby broaden the understanding of this phenomenon.

\section{THEORETICAL FRAMEWORK}

General systems theory formed the theoretical underpinning of this study (Von Bertalanffy, 1969). In general systems theory, a system has components that are identifiable; it is in constant interaction with its environment, and has specific functions. Similarly, families as systems have hierarchical structures and through interaction feed the family with resources to fulfil their need for staying connected. These systems do not function in isolation and are determined by their internal relationships (Visser, 2007), which create the opportunities for exchange and connectivity. The parts within the system thus influence one another and problematic behaviour can therefore not be blamed on only one individual (Lander, Howsare \& Byrne, 2013). The chosen theoretical framework provided the basis for the research methodology, which is described in more detail below. 


\section{METHODOLOGY}

The research sought to explore the nature of family connectedness in families dealing with adolescents in conflict with the law. It addressed the following research question: How is family connectedness perceived to be linked to families dealing with adolescents who are in conflict with the law?

\section{Research approach and design}

A qualitative approach was used to obtain insight into the identified problem. It provided in-depth data that detailed and gave meaning to the participants' experiences and their understanding of family connectedness (Lietz \& Zayas, 2010). This approach answered complex questions; it described the phenomenon from the perspective of the participant, and allowed the researcher to ascribe meaning to the participants' beliefs, feelings and experiences (Creswell, 2013). The employment of an exploratory descriptive design provided rich insights and accurate descriptions of the way in which the participants dealt with adolescents in conflict with the law, thus contributing to a deeper understanding of the phenomenon (Van Wyk, 2012).

\section{Selection of participants}

Participants were purposively selected based on predetermined criteria relevant to the phenomenon being researched (Rubin \& Babbie, 2008). In addition, the participants were family members of an adolescent between the ages of 14 and 17 years who was in conflict with the law. The social workers involved in the study have experience dealing with families with an adolescent in conflict with the law. Ten adolescents, ten family members, and five social workers comprised the sample for this study. Table 1 below provides a summary of the demographic information of the families. The biographical particulars of the social workers are as follows: the social workers were from the Department of Social Development, two of whom were male and three were female; the years of experience of the social workers ranged between 7 and 28 years, and they were all involved in the assessment of juveniles in conflict with the law, as well as rendering fieldwork services to families. The social workers were fluent in both Afrikaans and English, and were located within the boundaries of the Drakenstein Municipality in the Cape Winelands District in the Western Cape.

TABLE 1

\section{SUMMARY OF THE FAMILY PARTICIPANTS}

\begin{tabular}{|c|c|c|c|c|c|c|c|c|c|c|}
\hline & Uूँ & 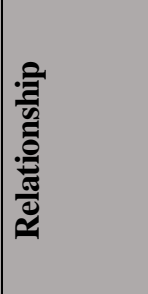 & 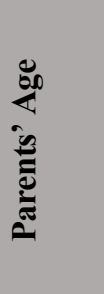 & 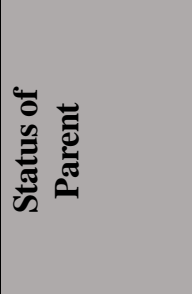 & 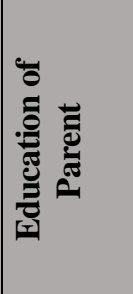 & 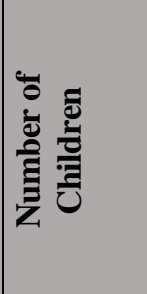 & 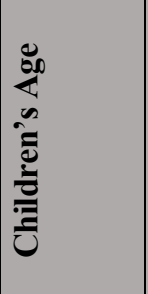 & 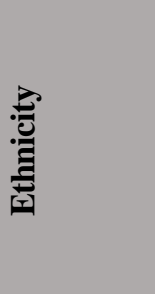 & 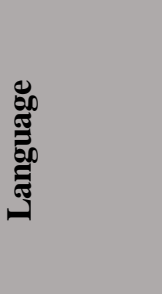 & 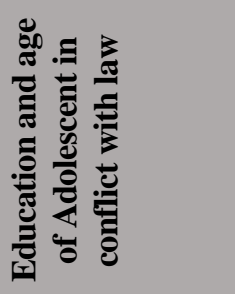 \\
\hline 1. & Male & Father & 30 & Married & Grade 10 & 3 & $\begin{array}{c}14,9,5 \\
\text { years }\end{array}$ & Coloured & Afrikaans & $\begin{array}{l}14 \text { years, male } \\
\text { Grade } 7\end{array}$ \\
\hline 2. & Female & Mother & 36 & Single parent & Grade 11 & $\begin{array}{c}2 \text { and } \\
\text { pregnant }\end{array}$ & $\begin{array}{l}17,10 \\
\text { years }\end{array}$ & Coloured & Afrikaans & $\begin{array}{l}17 \text { years' male } \\
\text { Grade } 12\end{array}$ \\
\hline 3. & Female & $\begin{array}{l}\text { Foster } \\
\text { mother }\end{array}$ & 58 & Married & Grade 7 & 4 & \begin{tabular}{|c|} 
Youngest \\
36 \\
months
\end{tabular} & African & isiXhosa & $\begin{array}{c}14 \text { years } \\
\text { female Grade } 7\end{array}$ \\
\hline 4. & Female & Mother & 50 & Divorced & Grade 7 & 5 & $\begin{array}{l}34,28, \\
22,16 \\
\text { years }\end{array}$ & Coloured & Afrikaans & $\begin{array}{l}16 \text { years, female } \\
\text { Grade } 9 \\
\text { Not attending } \\
\text { school }\end{array}$ \\
\hline 5. & Female & Mother & 49 & Divorced & Grade 10 & 4 & \begin{tabular}{|c|}
30,24, \\
21, \\
17 years
\end{tabular} & Coloured & Afrikaans & $\begin{array}{c}17 \text { years, male } \\
\text { Grade } 10 \\
\text { Not attending } \\
\text { school }\end{array}$ \\
\hline 6. & Female & Mother & 28 & Divorced & Grade 7 & 1 & 14 years & Coloured & Afrikaans & 14 years, male, \\
\hline
\end{tabular}

Social Work/Maatskaplike Werk 2020:56(3) 


\begin{tabular}{|c|c|c|c|c|c|c|c|c|c|c|}
\hline & & & & & & & & & & Grade 8 \\
\hline 7. & Female & Mother & 39 & Divorced & Grade 11 & 5 & $\begin{array}{l}22,15 \\
13,10 \\
\text { years }\end{array}$ & Coloured & Afrikaans & $\begin{array}{c}15 \text { years, male } \\
\text { Not attending } \\
\text { school }\end{array}$ \\
\hline 8. & Male & Father & 51 & Divorced & Grade 4 & 4 & \begin{tabular}{|c|}
15 years, \\
other ages \\
unknown
\end{tabular} & Coloured & Afrikaans & $\begin{array}{c}15 \text { years, male } \\
\text { Grade } 4 \\
\text { Not attending } \\
\text { school }\end{array}$ \\
\hline 9. & Female & Mother & 34 & Married & Grade 10 & 5 & $\begin{array}{c}15,11,8 \\
2 \text { and } 1 \\
\text { year }\end{array}$ & Coloured & Afrikaans & $\begin{array}{c}15 \text { years, female } \\
\text { Grade } 8 \\
\text { Not attending } \\
\text { school }\end{array}$ \\
\hline 10 & Male & $\begin{array}{l}\text { Brother of } \\
\text { adolescent }\end{array}$ & $\begin{array}{c}\text { Mother } \\
60 \\
\text { Father } 66\end{array}$ & Married & $\begin{array}{c}\text { un } \\
\text { known }\end{array}$ & 11 & \begin{tabular}{|c|}
50,40, \\
$30-40,25$ \\
and 17 \\
years
\end{tabular} & Coloured & Afrikaans & $\begin{array}{l}17 \text { years, male } \\
\text { Grade } 10\end{array}$ \\
\hline
\end{tabular}

\section{Data collection}

The semi-structured interviews were conducted with three separate interview guides; they lasted between 45-60 minutes and were conducted with parents, adolescents and social workers. These guides were developed and piloted on an adolescent, a parent and a social worker, who did not form part of the main study. The pilot study was conducted to address weaknesses in the research design, adjust the interview guide and determine the time needed for conducting the interview (De Vos, Strydom, Fouche \& Delport, 2012). Semi-structured interviews were conducted in a setting where they felt most comfortable until data saturation was reached, in other words, when new and additional information will no longer add value to the study (Saumure \& Given, 2008). Interviews were audio-recorded with the permission of the participants.

TABLE 2

INTERVIEW-GUIDE QUESTIONS: ADOLESCENTS

\begin{tabular}{|c|l|}
\hline \multicolumn{2}{|l|}{ Interview Guide: Questions } \\
\hline 1. & Tell me about the family that you are staying with? \\
\hline 2. & Tell me about the routines that you have in your family? \\
\hline 3. & Tell me about the values and traditions that your family have? \\
\hline 4. & Tell me about the challenges that you experience when your parents discipline you? \\
\hline 5. & $\begin{array}{l}\text { Tell me how your family reacted and treated you when they heard you were in conflict with the } \\
\text { law? }\end{array}$ \\
\hline 6. & Tell me about the relationship you have with your family? \\
\hline
\end{tabular}

\section{TABLE 3}

\section{INTERVIEW-GUIDE QUESTIONS: PARENTS/FAMILY MEMBER}

\begin{tabular}{|c|l|}
\hline \multicolumn{2}{|c|}{ Interview Guide: Questions } \\
\hline 1. & Tell me about the relationship between the family members? \\
\hline 2. & Tell me about the routines in the family? \\
\hline 3. & Tell me about the rituals in the family? \\
\hline 4. & How do you involve your adolescent in the routines and rituals in the family? \\
\hline 5. & $\begin{array}{l}\text { Tell me about your feelings and reaction when the adolescent was involved in conflict with the } \\
\text { law }\end{array}$ \\
\hline 6. & Tell me about the rules and discipline that you have in your family? \\
\hline
\end{tabular}




\begin{tabular}{|l|l|}
\hline \multicolumn{2}{|c|}{ Interview Guide: Questions } \\
\hline 1. & Tell me about your experiences dealing with adolescents in conflict with the law? \\
\hline 2. & Tell me about your experiences with families that are unable to discipline their children? \\
\hline 3. & Tell me about the rituals in these families? \\
\hline 4. & Tell me about the routines that are in these families? \\
\hline 5. & Tell me about the family's reaction towards their children that are in conflict with the law? \\
\hline 6. & Tell me about the disciplinary style of these families? \\
\hline
\end{tabular}

\section{Data analysis}

Tesch's eight steps were used to transcribe, code and organise the collected data into themes for a systematic understanding of the data (Creswell, 2009).

\section{Ethical aspects}

Permission was granted to conduct this study by the University of the Western Cape's Senate Research Committee and the researcher adhered to the ethical guidelines for researchers as stipulated by the University of the Western Cape. The Department of Social Development was approached for permission to make use of their databases and the local office manager was informed about the ethical standards that the researcher would adhere to.

\section{Trustworthiness}

Credibility in this study was achieved through the realistic representation of the experiences of the participants and their understanding of the phenomenon (Babbie, 2014). The participants gave their informed consent and their inclusion in the study was voluntarily. Interviews were conducted in a setting where the participants felt most comfortable. They were also informed that the data obtained from the interviews would be dealt with in a credible manner. Dependability was ensured through the use of the same interview schedules and methods employed to collect and transcribe the data (Creswell, 2013). This ensured the credibility, transferability and validity of the study (Babbie, 2010). Reflexivity enabled the researcher to monitor the data and acknowledge the influence of previous knowledge and interests on the study (Creswell, Klassen, Plano, \& Smith, 2011; Polit \& Beck, 2004; Krefting, 1991).

The following ethical principles were observed in this study: participants were informed that no harm would be done to them, and that confidentiality and anonymity would be maintained.

The section below highlights the main findings of the study. The limitations of this study were mainly a consequence of its contextual nature.

\section{FINDINGS}

The following themes emerged from the collected data: (1) family connectedness, (2) routines, rituals and traditions, and (3) families dealing with adolescents in conflict with the law. For the purpose of this study, the following two themes will be discussed in the sections below: family connectedness and families dealing with adolescents in conflict with the law.

\section{Theme 1: Family connectedness}

This study encompassed a broad diversity of family and household forms. However, there was a high prominence of female-headed single-parent families. The degree of connectedness in these families was ascertained through the physical presence of family members, mutual interests and interaction, daily support, and experience of closeness. Participants measured their connections with the family by the parental figures present in their lives, parental showing of responsibility, and the support they received from one another. General systems theory supports the notion that if families are involved in one another's lives, they will mutually influence one another, which in turn determines the quality of their interactions (Hepworth, Rooney, Rooney, Strom-Gottfried \& Larsen, 2009; Kieran, Munford, O’Donoghue \& Nash, 2005; Lewis, 2005). Families that experience a breakdown in their relationships 
become less available to one another. Consequently, this impacts on the support, responsibility and behaviour of its members.

Most of the participants were living in divorced or single-parent families, with few being reared in twoparent households. The single-parent mothers had to cope with limited support, having to work (sometimes irregular or long hours), and yet remain available to their adolescent children. This placed a burden on these single-parent mothers to fulfil these tasks with less time to monitor, provide support and guidance, and care for the adolescent. The participants from these divorced and single-parent families experienced significant frustration due to their irregular working hours, being unable to set clear boundaries, and inability to monitor the whereabouts of the adolescent.

Because I work shifts now, it seems to them, they are on their own. They, they can only do what they want. (Parent 5)

There are rules, but they do not follow the rules when they need to be early [in the house], dinnertime when it is time to eat, and when they have to pack their clothes and so on. (Parent 7)

They do not set clear boundaries for the child, for example, what is the child's tasks at home, are not adaptable to what the child wants or needs, or they set unclear limits and then allow the child to do what he or she wants to do. (Social worker 4)

The comments above show that the single-parent mothers and those from divorced families have less available time to guide, support and monitor the adolescent, which puts them at risk of involvement in delinquent behaviour. Family composition influences the parent-adolescent relationship and the anguish experienced within these relationships (Bastaits \& Mortelmans, 2014). Parents who are not available become uninvolved in the adolescent's life. This suggests that they are unable to set boundaries, which affects the warmth and support felt by the adolescent, influencing the parents' monitoring function. This further results in a loss of control over daily interactions with the adolescent, as they find it difficult to define clear roles and build or maintain relationships within the family (Putnick, Bornstein, Hendricks, Painter, Suwalsky \& Collins, 2008). Systems theory emphasises that the absence of family members, lack of support and limited resources lead to changes in the systems environment and interactions between components (Meadows, 2008). Adolescents in return become less willing to adhere to household rules and boundaries. Adolescent participants responded to this situation by withdrawing from their family and becoming less involved in family activities. They also described their non-adherence to parental rules, roaming the streets, dropping out of school, and involvement in delinquent behaviour.

Most of the time he is outside. He just wants to be on the street, my mother has already talked to him, but he does not want to. He's like the one that wants but then he is still doing it anyway. (Older brother 10)

I went to school in the mornings. My mother sends me to school, but I absconded from school and walk my own way. (Adolescent 7)

The comments above show that adolescents in conflict with the law reject parental authority or guidance, which exposes them to negative friendships and absconding from school. The boundaries between the parent and the adolescent are affected when the parent is not able to provide direction or influence the decision-making of the adolescent. The parents in the study became frustrated and mentioned that the adolescent no longer listens to them.

I speak to him then it seems I am just talking to myself. He also doesn't want to go with us anymore and does not go to school. There where we stay, they, fight and he is part of the stone throwers. When I come home the people tell me he was part of the stone throwers. (Parent 5) 
When I talk to her, she does not take notice of me. She is more involved with her friends. (Parent 3)

Communication between the adolescent and parent is affected when the parent feels ignored, disregarded or not listened to. Consequently, the parents become unaware of the adolescent's behaviour outside the family home. A lack of constructive communication between the parent and the adolescent influences the input a parent can make and the impact that a parent can have on the adolescent. Dallos and Vetere (2012) state that when adolescents withdraw from the family, they become more reliant on negative peer influence and exposed to risky behaviours. Systems processes are dependent on the inputs that the parent provides and how they are received. When this is absent, the system becomes dysfunctional. In addition, where parental supervision is limited or even non-existent, the adolescent becomes absent in the family environment and more exposed to negative friendships, in turn influencing parent-adolescent connectedness (Vitulano, Fite \& Rathert, 2010; Blomberg, Bales \& Piquero, 2012). Poor communication is therefore linked to a lack of parental supervision and strained parent-adolescent relationships (De Los Reyes \& Laird, 2013). It is therefore noted that the communication between the adolescent and the parent determines their mutual interaction and the influence that they have on one another and their interactional processes (Meadows, Randers \& Meadows, 2004; Raphesu, 2005).

I mean if I'm making an example, they [family] never tell you something that makes you feel right, maybe if you've failed now, they're telling you, you're stupid and no good. Ha, sometimes people believe what they say, that is why one does not even have the energy to go to school again. (Adolescent 3)

With $C$, the second oldest one, we totally don't talk, we say ugly things to another. Stay out of my way. Don't touch me. D will give me a little bit of money, or whatever. He is smaller than me, but if I ask him, he says no in my face. L, they make her negative against me... go wash your stuff, you're kidding with boys, you are using tik and she's 2 years old. She does not share anything with me. My mom makes her say those things and then they laugh. Sometimes I get cross and then sometimes I get angry and then I do anything irresponsible. (Adolescent 9)

The adolescents in this study felt that if the parents fail to speak positively to them or their siblings, it influences their goal setting and interaction with their siblings. It is evident that this environment generates anger and unhappiness. It is understood that parental responses or reactions contribute to how adolescents perceive their own behaviour, which affects their responses and relationship with their parent. Adolescents are prone to risky behaviour when they are unhappy at home, or feel unloved and rejected (Stoddard, Whiteside, Zimmerman, Cunningham, Chermack, \& Walton, 2013). In this regard, the systems perspective allows an insightful understanding of the importance of the social and emotional inputs that reinforce positive systems' functioning.

The results indicated that the participants perceived the relationships and atmosphere in their families to be filled with tension and conflict, impacting on family and community connectedness. The research clearly shows that when adolescents are connected to family, they stay in school longer and adapt to the school environment (Stoddard, McMorris, \& Sieving, 2011). But when relationships are strained and the atmosphere in the home is filled with tension and conflict, this negatively influences the adolescent's connectedness with family and the community, as the participants pointed out. One social worker described the conflict that occurs in these households as follows:

Their behaviour in the house creates a lot of conflict and they don't understand each other in the house. This behaviour creates, more violence towards the parent and towards the rest of the community members, because for instance you might get the child who assault someone because of the anger that he builds up in him or herself, due to the household experiences. (Social worker 1) 
In addition, one of the adolescents mentioned her experience of conflict in the household and the impact of that on her family relationships.

Of the things my mom is doing, maybe her substance abuse problem, then she does things differently, she hit me or something, spiteful effort. And so, I decided I'm not going to school anymore, and they cannot tell me. Yes, if he is angry with my mom, then he's going to the bar on Fridays, then he drives and then he arrives in the morning, Saturday morning, so there's nothing to eat. Sometimes I get angry and I want to ask guys to make his wheels flat at the bar or I come in when I want to at home, he is not going to tell me what to do. He is an irresponsible parent. (Adolescent 8)

Family environments where conflict is a daily occurrence, as seen in this study, leads to an increase in tension, instability and the weakening of family relationships. To highlight the consequences of these conflicts, Kennedy, Edmonds, Dann and Burnett (2010) point out that these adolescents often assault or verbally abuse their parents. Some of the participants confirmed that they have been deceitful or disrespectful in their interactions with their parents.

Sometimes my mother says I cannot go, then I say, I'm going to visit next door, then I'm going and then I'll be back again, sometimes. One of the values my mother teaches me is not to lie to her. I do now lie to her. (Adolescent 4)

She just stands up and ask what I am going to eat, and then she throws me with the bread rolls. I did not answer and just sat. When I talk to her, she does not listen to me. She is more involved with the friends she became involved with. (Parent 9)

Sometimes I hear them speak disrespectful to their mother, I have to jump in. I just hear him talk like that. Then I tell him he must keep his mouth shut and listen to his mother, listen when his mother sends him, he must go. (Parent 8)

This was reiterated by another participant who mentioned that there is limited openness and honesty in the parent-adolescent relationship, with adolescents not being honest about their behaviour.

He is not honest with her because she has to hear stuff about him from people outside, and then he says he was not at all involved. (Older brother 10)

In line with the descriptions above, adolescents in conflict with the law who experience conflict within the household or have a dysfunctional relationship with their parent/s tend to display dishonesty in their conduct, tell lies and become disrespectful towards their parents. It is evident that these relationships lack openness about the adolescent behaviour with the parent. Adolescents in conflict with the law become more open to dysfunctional friendships that are more accepting of their behaviour. Lindahl (2012) notes that adolescents who undermine the values of the family experience shame and blame for their behaviour. Furthermore, the trust and dependency within the parent-adolescent relationship are minimised. Trust is essential for the strengthening of relationships and forms the basis for socialisation (Barber \& Schluterman, 2008).

Permissive and uninvolved parenting contributes towards adolescent involvement in delinquent behaviour and limited parental engagement (Prioste, Narciso, Goncalves \& Pereira, 2015). It is noted that permissive parents have limited expectations and control over their children and tend to have the least expectation of adolescents taking responsibility for their actions (Baumrind, 2005; Ahmadi \& Saadat, 2015). Kim and Rose (2014) state that if the feedback patterns and the systems outputs become dysfunctional, this reduces the family system's equilibrium and ability to stay connected. Adolescents revealed that they were unhappy with their mothers who showed no concern towards them or their behaviour.

But if my mother is drunk, she will not even worry about me, she will just entertain her friends. (Adolescent 5) 
My mother said she will not come with me, that day when the detectives picked me up, she said, she did not care about such things. She did not tell me what I should do or not supposed to do. (Adolescent 10)

The adolescent participants felt overwhelmed by their mothers' limited involvement in their lives, resulting in them reaching out to peers who had a negative influence, becoming early school-leavers, and engaging in destructive behaviours. The need for warmth and support in the relationship with the mother was seen as a way in which guidance could be provided to the adolescent. In addition, adolescent participants expressed disappointment with their biological fathers who spent very little time with them.

I stay with my mother. My mother and father is divorced. I only see him [father] sometimes and then maybe on a weekend. He just greets me then he walks past me. He never gives me something. (Adolescent 7)

My father drinks a lot and so. I do not go there anymore. [He] drink too much, when I go there, he is drunk, that is why I don't go there regularly. Yes, I do talk to him but not what I actually want to say or ask. (Adolescent 4)

It is clear that the physical and emotional absence of biological fathers in these families had a significant impact on the adolescent. In addition to the fathers' lack of concern, there was also very little or no contribution to the financial and social welfare of the adolescent. Furthermore, the fathers who were not living with the adolescents had the least contact with or made the lowest contribution towards the development of the adolescent in conflict with the law. Fathers who do not live in the same household as the adolescent tend to have limited emotional involvement with the adolescent or talk less with them about their personal issues (Hawkins, Amato \& King, 2006; King \& Sobolewski, 2006). The quality of the parent-child relationship influences the behaviour of the adolescent and their involvement in delinquent behaviour (Richter \& Morell, 2006; Craigie, Brooks-Gunn \& Waldfogel, 2010). Parental substance abuse reportedly impeded the building of connectedness with the adolescent. Such parents in this study exhibited erratic behaviour, poor role modelling and inconsistent rule setting, thus exacerbating the adolescents' rebellious behaviour and disconnection from school.

My mother is also coming drunk home over weekends. Then I have to wait for her all the time, I do not want to go to sleep. When my mother knocks, my mother is scolding me. Then I stay awake the whole night long to open the door when my mother knocks, but still my mother scolds me, then I will let her go on and then I will go to sleep. (Adolescent 5)

Of the things my mom is doing, maybe her substance abuse problem, then she does things differently, she hit me or something, spiteful effort. And so, I decided I'm not going to school anymore, and they cannot tell me. (Adolescent 8)

Substance abuse in this study affected the functioning of families, their daily interactions and their closeness with one another. Limited parental attention and support, and dependency on one another, influenced parental warmth and cohesion within the family. Poor communication, lack of support and limited cohesion resulted in adolescents becoming withdrawn from their family (Stanger, Dumenci, Kamon \& Burstein, 2004). Families that experience limited or poor communication tend to feel helpless and frustrated with the adolescent who experiences feelings of hostility (Hitzeroth \& Kramer, 2010). A lack of positive role modelling of behaviour by the parent results in adolescents not adhering to parental discipline and being involved in delinquent behaviour. Therefore, the relationship with the parent and the role modelling of the parent has a direct influence on how the adolescent behaves, with whom he/she associates, and his/her association with friends who have a negative influence (GaultSherman, 2012).

Family connectedness is influenced by the mutual relationship between the parent and adolescent, the dysfunctional family environment and the system's ability to create balance. Insecure connections 
affect the levels of trust, attention and ability to depend on one another. Therefore, most of these adolescents developed an unfulfilled sense of belonging with the family and an involvement in delinquent behaviour.

A lot of them come from situations, where the adolescent normally lacks, I would say a sense of belonging a sense of worth, a sense of dignity that is my experience. The adolescent then doesn't really have clear a vision, a clear goal for himself. (Social worker 2)

In line with the above, family members described a limited sense of connectedness, which influenced the adolescent's sense of belonging and their interaction within the family. These families therefore noted that connectedness within the family influences how they deal with adolescents in conflict with the law. The following section addresses the link between family connectedness and how they deal with adolescents in conflict with the law.

\section{Theme 2: Families dealing with adolescents in conflict with the law}

Most of the families in this study dealing with adolescents in conflict with the law were female-headed households with limited support from the biological father. In addition, these mothers who themselves lacked support had to deal with the behaviour of their delinquent children, whilst continuing to render support, guidance and leadership. Therefore, the parenting of the single-parent mothers is linked to they way they deal with their adolescents who are in conflict with the law. In line with this, Visser (2007) states that leadership and parenting capabilities are highly dependent on the inputs and resources within the system and control the feedback, corrective action and the system's ability to maintain balance. It is noted that most of these mothers have to parent in a strained environment where there is limited income. In addition, they have to work irregular hours, sacrificing work hours to support their children at court and provide sustenance for their households. One of the mothers voiced her frustration by stating that she has to care and be responsible for her children with no support from the father.

All the time, I am responsible for caring for the children, without the maintenance of the father and whatever. (Parent 4)

Single parenting by mothers with limited support is linked to limited parental interaction and adolescent delinquent behaviour (Baumrind, 2005; Hoeve, Blokland, Dubas, Loeber, Gerris \& van der Laan, 2008). Social worker participants supported the notion that these single parent mothers have to parent under difficult circumstances and still show their responsibility and support when the adolescent comes into conflict with the law.

Mostly the mothers that come to court, just now and then you see both parents in court, there is very few, but it is mostly the mothers that come to court. They have to deal with this child, with this behavioural problem child. Sometimes it is very difficult for the mother because she might also go to work. (Social worker 1)

Most of these mothers expressed unhappiness with the behaviour of the adolescent and felt that their parenting role was threatened by the delinquent behaviour of the adolescent.

I do not really feel happy about it, because then I have to stay out of work to go to court with him, and this is all things. I can lose my job. (Parent 8)

Then I felt very, very unhappy. I almost felt I could beat him, I was very sad because I did not even use it, so why did he. (Parent1)

Anger, sadness, feelings of unhappiness, blame, shame and guilt were some of the emotions expressed by the mothers. Their retaliation was directed towards the adolescent in the form of threats of harsh punishment, or blame, influencing their emotional availability to the adolescent.

So I have to be harsh, where I can. So that is why I hit them, I don't let children determine what I should do. I do not allow what other parents allow. At the end of the day your child is what you allow. You need to control them. (Parent 4) 
They hit me sometimes so much, but for this month they did not touch me. I told them that they should not beat me anymore. They are my mother and father and should not touch me like this, because it is wrong to hit me every time. (Adolescent 9)

Now I have a different way that I punish him, I keep him in the house, I start to keep him detained within the house if he has done something wrong. I ignore him and don't talk to him or don't give him an answer when he talks to me. (Parent 6)

The highly emotional reaction of parents and their threats of harsh punishment limits the adolescents' management of their own behaviour, echoes ineffective role modelling of the part of the parent, and raises the possibility of engagement in delinquent behaviour (Lunkenheimer, Ram, Skowron \& Yin, 2017; Ross \& Howe, 2009). It is noted that the emotional feelings of the adolescent are linked to the nature of the parent-adolescent relationship, the family environment and delinquent behaviour of the adolescent (Soloski \& Berryhill, 2015). Therefore, it is noted that the way in which the parent responds to the adolescent contributes to the way that the adolescent perceives his/her own behaviour and the quality of interaction with the parent.

I mean if I'm making an example, they [family] never tell you something that makes you feel right, maybe if you've failed now, they're telling you, you're stupid and no good. Ha, sometimes people believe what they say, that is why one does not even have the energy to go to school again. (Adolescent 3)

My mother stresses a lot, and then I must stand up and do what she wants. Every evening there is no food in the house then I must go look for food. (Adolescent 7)

We stay in a little house; the thing is my dad watches movies every day. He's at home now 2 o'clock, 3 o'clock in the night he watches TV. Now there's a speaker that he has connected to the DVD, now when he puts it on at night, I wake up then I can't sleep anymore. It is also very cold, and I cannot sleep well. He says it is no problem for him. If I tell him then he wants to say to me, you cannot tell me, the DVD belongs to me. That is why I do not watch TV anymore. Watching TV is also a problem. (Adolescent 10)

The literature states that anger leads to the expression of unhappiness, which creates a breakdown in the parent-adolescent relationship, specifically when yelling, spanking and blaming occurs (Baumeister, Stillwell \& Heatherone, 1994; Dearing \& Tangey, 2011). In line with the above, parents expressed the sacrifices they have had to make for the sake of their children to keep them at home and away from negative friends.

I was very upset, then I said, what is $F$ doing now. He wants to live like this, and I sacrificed myself to keep him in school. (Parent 5)

Last time, I bought him a computer just to make sure he is at home and do not get involved with the wrong friends. I watch him, from here on. (Parent 1)

We look after her, we make sure that there is bread to eat. Make sure there is some food. Children have to eat. We don't want the children to ask for food at other people's houses.

(Parent 4)

The parent participants felt that they had made significant sacrifices to put mechanisms in place to prevent the adolescent from coming into conflict with the law, but that the adolescent's behaviour showed the opposite reaction. Parental disappointment and dissatisfaction with the adolescent's behaviour resulted in unmet needs within the family system and the parents becoming over-involved in the adolescent's connectedness with friends. Parents, as seen in the study, wanted to make choices for the adolescents and changed the interactional patterns in the family. The literature states that if there is a lack of parental interaction or crisis intervention by the parent, it influences the adolescent's development of self-esteem and their secure connection with the parent negatively (Gault-Sherman, 
2012). Change in interactional patterns in either the mother or father contributes to conflict within the parent-adolescent relationship, and undermines the support that could be rendered and the possibility of conflict resolution (Düşek \& Ayhan, 2014). In line with this, most participants mentioned that their parents only became involved in their peer connections after they came into conflict with the law or started to seek help outside the boundaries of the family as a way in coping with their delinquent behaviour.

My mother has a problem with them. She says they are not the real friends for me. I have to stay away from them. I feel that they are my friends. Then I say no, that is my friends. She cannot choose my friends and I do not choose her friends; it is my friends. (Adolescent 10)

In line with the above, it is noted that parental intervention after the delinquent behaviour has occurred led to parent-adolescent conflict and rebellion. The breakdown in the relationship and the lack of involvement of the adolescent in the decision-making led to the adolescent not accepting parental decision-making or interventions. The mutual relationship between the parent and the adolescent is built on love, respect and support, and has a direct influence on the positive decision-making of the adolescent. However, if the adolescent resists parental intervention, the parent becomes powerless, rendering the adolescent more exposed to negative friendships and delinquent behaviour. Family stress limits the ability of the parent to determine positive boundaries and to provide guidance in the choice of friends (Young, Fitzgibbon \& Silverstone, 2013). Therefore, if the feedback patterns in the system are unable to self-correct, the function of the system will reinforce dysfunctionality in the parent-child relationships. The above is supported by a statement by one participant about his mother's unwillingness to support him during his arrest or even after the incident occurred.

My mother said she will not come with me, that day when the detectives picked me up, she said, she did not care about such things. She did not even tell me I should do this or that. (Adolescent 10)

Families dealing with adolescents in conflict with the law are influenced by the connectedness within the parent-adolescent relationships. In this study, it was evident that weak family bonds rendered the parent powerless to help or provide the necessary support to the adolescent. In relation to the above, the general systems theory provides evidence that systems influence one another and that these in turn influence how problematic matters are dealt with within the system (Senekal, 2013).

\section{CONCLUSION AND RECOMMENDATIONS}

The families in the study were bound by their connections and interactions that influenced their goals and the quality of their connectedness. The results of this study showed that most of the parents were single parents, particularly single mothers. Their limited support restricted their ability to parent and deal with the adolescent in conflict with the law. Parents became frustrated, angry and stressed, exacerbating the dysfunctional interaction patterns and negatively influencing the parenting process. This contributed to weakened parent-adolescent relationships and the adolescents becoming more reliant on negative friendships and risky behaviour, coming into conflict with the law. Withdrawal or disengagement of either the parent or the adolescent in the family led to family members becoming less involved with one another and the acceptance of each other's values. The behaviour of the adolescent became increasingly difficult to deal with. This subsequently led to involvement in behaviour that brought them in conflict with the law.

Parents who were not physically present or lacked attentiveness to the adolescents' needs had a negative influence on the parenting process and the connectedness with the adolescent. Furthermore, parental substance abuse weakened the relationship with the adolescent, with them feeling unhappy and distressed by the lack of parental interest. This in turn impacted on the flow of communication within the family system, with adolescents becoming more open to destructive influences within the community. The findings thus show that there is a link between family connectedness and the way families deal with adolescents in conflict with the law. 
Service delivery to families should ensure that a safe environment is created for adolescents to strengthen their connectedness with the immediate family members, specifically their parents. Specific parenting programmes should be developed to support and ensure the active participation of singleparent mothers in the parenting process and the fostering of connectedness with their children. The empowerment of the single-parent mother through counselling would also contribute to the availability of skills within the family and would influence conflict resolution, monitoring of the children and their daily interaction. However, the father's contribution in the life of the adolescent seemed to be pivotal to the wellbeing of the adolescent and counselling should focus on the inclusion of the biological fathers in the service delivery process. Social workers should stress the importance of the time that fathers spend with their children, the quality of the interaction and their presence in the adolescents' lives. They should also clearly explain the influence this has on bonding with one another and the development of young adolescents' connections with significant others. In addition, counselling should focus on substance abuse in families, coping mechanisms for the family and strengthening family relationships.

This article emphasised that if families stay connected with one another, this influences they way they deal with the behaviour of their children. Family connectedness then contributes positively to the parenting process and the daily interaction within families, and leads to the wellbeing of its members.

\section{REFERENCES}

AHMADI, K., \& SAADAT, H. 2015. Contribution of marital stability to parenting styles: A crosssectional study of Iranian mothers in intact marriages. Journal of Child and Family Studies, 24(7): 2155-2163.

BABBIE, E. 2010. The practice of social research $\left(12^{\text {th }}\right.$ ed). USA: Wadsworth Cengage Learning. BABBIE, E. (2014). The basics of social research $\left(6^{\text {th }}\right.$ ed). USA: Wadsworth Cengage Learning.

BARBER, B. K., \& SCHLUTERMAN, J. M. 2008. Connectedness in the lives of children and adolescents: A call for greater conceptual clarity. Journal of Adolescent Health, 43(3): 209-216.

BASTAITS, K., \& MORTELMANS, D. 2014. Does the parenting of divorced mothers and fathers affect children's well-being in the same way? Child Indicators Research, 7(2): 351-367.

BAKER, L. A., \& MUTCHLER, J. E. 2010. Poverty and material hardship in grandparent-headed households. Journal of Marriage \& Family, 72(4): 947-962.

BAUMEISTER, R. F., STILLWELL, A. M., \& HEATHERON, T. F. 1994. Guilt: An interpersonal approach. Psychological Bulletin, 115(2): 243-267.

BAUMRIND, D. 2005, Patterns of parental authority and adolescent autonomy. New Directions for Child and Adolescent Development, (108): 61-69. doi:10.1002/cd.128

BLOMBERG, T. G., BALES, W. D., \& PIQUERO, A. R. 2012. Is educational achievement a turning point for incarcerated delinquents across race and sex? Journal of Youth and Adolescence, 41(2): 202-216.

CAVENDISH, W., MONTAGUE, M., ENDERS, C., \& DIETZ, S. 2014. Mothers' and adolescents' perceptions of family environment and adolescent social-emotional functioning. Journal of Child \& Family Studies, 23(1): 52-66. doi:10.1007/s10826-012-9685

CHEN, E., BRODY, G. H., \& MILLER, G. E. 2017. Childhood close family relationships and health. American Psychologist, 72(6): 555.

CLARK, R. M. 2010. Childhood in society for early childhood studies. Great Britain: SAGE.

CRAIGIE, T., BROOKS-GUNN, J., \& WALDFOGEL, J. 2010. Family Structure, Family Stability and Early Child Wellbeing, Unpublished manuscript, Princeton University, Princeton, NJ.

Social Work/Maatskaplike Werk 2020:56(3) 
CRESWELL, J. W. 2009. The selection of a research design. Research Design: Qualitative, quantitative and mixed methods approaches. Thousand Oaks, CA: Sage Publications.

CRESWELL, J. W. 2013. Research design: Qualitative, quantitative, and mixed methods approaches. $\left(3^{\text {rd }}\right.$ ed). London: Sage Publications.

CRESWELL, J. W., KLASSEN, A. C., PLANO CLARK, V. L., \& SMITH, K. C. 2011. Best practices for mixed methods research in the health sciences. Bethesda, Maryland: National Institutes of Health.

DALLOS, R., \& VETERE, A. 2012. Systems theory, family attachments and processes of triangulation: Does the concept of triangulation offer a useful bridge? Journal of Family Therapy, 34(2): 117-137. doi:10.1111/j.1467-6427.2011.00554

DEARING, R. L., \& TANGNEY, J. P. E. 2011. Shame in the therapy hour. American Psychological Association. [Online] Available: http://dx.doi.org/10.1037/12326-000 [Accessed: 15/5/2016].

DE LOS REYES, A., OHANNESSIAN, C. M., \& LAIRD, R. D. 2016. Developmental changes in discrepancies between adolescents' and their mothers' views of family communication. Journal of Child and Family Studies, 25(3): 790-797.

DEPARTMENT OF SOCIAL DEVELOPMENT. 2013a. White Paper on families in South Africa. Pretoria: Government Printers.

DEPARTMENT OF SOCIAL DEVELOPMENT. 2013b. A Draft Youth Development Strategy for the Western Cape Department of Social Development: Youth of the Western Cape Meeting the Challenges of the 21st Century. Cape Town: Department of Social Development.

DE VOS, A. S., STRYDOM, H., FOUCHÉ, C. B. \& DELPORT, C. S. L. 2012. Research at grassroots: For the social science and human service professions (3rd ed). Pretoria: Van Schaik Publishers.

DüSEK, G., \& AYHAN, A. B. (2014). A study on problem solving skills of the children from broken family and full parent's family attending regional primary boarding school. Procedia - Social and Behavioural Sciences, 152: 137-142.

ELLIS, C., \& ADAMS, W. 2009. Towards a 10-year review of the population policy implementation in South Africa (1998-2008): Families, households and children. South Africa: Department of Social Development.

GAULT-SHERMAN, M. 2012. It's a two-way street: The bidirectional relationship between parenting and delinquency. Journal of Youth and Adolescence, 41(2): 121-145.

GOLDWEBER, A., DMITIEVA, J., CAUFFMAN, E., PIQUERO, A., \& STEINBERG, L. (2011). The development of criminal style in adolescence and young adulthood: Separating the lemmings from the loners. Journal of Youth \& Adolescence, 40(3): 332-346. doi:10.1007/s10964-010-9534-5

HADŽIKAPETANOVIC, H., BABIC, T., \& BJELOŠVIC, E. 2017. Depression and intimate relationships of adolescents from divorced families. Medicinski Glasnik, 14(1): 132-138.

HAGHDOOST, A., ABAZARI, F., ABBASZADEH, A., \& DORTAJ RABORI, E. 2014. Family and the risky behaviours of High School students. Iranian Red Crescent Medical Journal, 16(10): e15931. [Online] Available: http://doi.org/10.5812/ircmj.15931. [Accessed: 21/04/2016].

HALL, K, RICHTER L, MOKOMANE Z \& LAKE L (eds). 2018. South African Child Gauge 2018. Cape Town: Children's Institute, University of Cape Town.

HAN, W., MILLER, D. P., \& WALDFOGEL, J. 2010. Parental work schedules and adolescent risky behaviours. Developmental Psychology, 46(5):1245-1258. 
HAWKINS, D. N., AMATO, P. R., \& KING, V. 2006. Parent-adolescent involvement: The relative influence of parent gender and residence. Journal of Marriage and Family, 68(1): 125-136.

HEPWORTH, D. H., ROONEY, R. H., ROONEY, G. D., STROM-GOTTFRIED, K., \& LARSEN, J. A. 2009. Direct social work practice: Theory and skills. Belmont. Cengage Learning.

HITZEROTH, V. \& KRAMER, L. 2010. The end of addiction. A comprehensive South African guide. Cape Town: Human \& Rousseau.

HOEVE, M., BLOKLAND, A., DUBAS, J. S., LOEBER, R., GERRIS, J. R., \& VAN DER LAAN, P. H. 2008. Trajectories of delinquency and parenting styles. Journal of abnormal child psychology, 36(2): 223-235.

HOLBORN, L., \& EDDY, G. 2011. First steps to healing the South African family South African Institute of Race Relations. Qualitative Report, 8(4): 597-606.

HUI, C. M., MOLDEN, D. C., \& FINKEL, E. J. 2013. Loving freedom: Concerns with promotion or prevention and the role of autonomy in relationship well-being. Journal of Personality and Social Psychology, 105(1): 61.

HUMMEL, A., SHELTON, K.H., HERON, J., MOORE, L., \& BREE, M. B. M. 2013. A systematic review of the relationships between family functioning, pubertal timing and adolescent substance use. Addiction, 108(3): 487-496. doi:10.1111/add.12055

JESURAJ, M. J. 2012. Impact of substance abuse on families. Rajagiri Journal of Social Development, 4(2): 33-44.

KENNEDY, T. D., EDMONDS, W. A., DANN, K. T., \& BURNETT, K. F. 2010. The clinical and adaptive features of young offenders with histories of child-parent violence. Journal of Family Violence, 25(5): 509-520.

KIERAN, O., MUNFORD, R., O'DONOGHUE, K., \& NASH, M. 2005. Social work theories in action. London. Jessica Kingsley Publishers.

KIM, H., \& ROSE, K. M. 2014. Concept analysis of family homeostasis. Journal of Advanced Nursing, 70(11): 2450-2468.

KING, V., \& SOBOLEWSKI, J. M. 2006. Non-resident fathers' contributions to adolescent well-being. Journal of Marriage and Family, 68(3): 537-557.

KREFTING, L. 1991. Rigor in qualitative research: The assessment of trustworthiness. American Journal of Occupational Therapy, 45(3): 214-222.

LAIZANE, I. 2012. Adolescent behaviour problems and co- dependence in dysfunctional family context. Engineering for rural development - International Scientific Conference, 11, 633-637.

LANDER, L., HOWSARE, J., \& BYRNE, M. 2013. The impact of substance use disorders on families and children: From theory to practice. Social Work in Public Health, 28(3): 194-205.

LEWIS, S. 2005. Who was Ludwig von Bertalanffy. Biologist, 52(3), 174-175.

LIETZ, C. A., \& ZAYAS, L. E. 2010. Evaluating qualitative research for social work practitioners. Advances in Social Work, 11(2): 188-202.

LINDAHL, L. 2012. Position and change: A study in law and logic, (Vol. 112). Springer Science \& Business Media.

LUNKENHEIMER, E., RAM, N., SKOWRON, E. A., \& YIN, P. 2017. Harsh parenting, child behaviour problems, and the dynamic coupling of parents' and children's positive behaviours. Journal of Family Psychology. 31(6): 689-698. 
MAKIWANE, M., \& BERRY, L. 2013. Towards the development of a family policy for South Africa. Policy in Brief. Pretoria: HSRC.

MEADOWS, D. H. 2008. Thinking in systems: A primer. Vermont. Chelsea Green Publishing.

MEADOWS, D. H., \& RANDERS, J., MEADOWS, D. 2005. Limits to growth: The 30-year update. Vermont. Chelsea Green Publishing.

MOORE, K. A., KINGHORN, A. J., \& BANDY, T. 2011. Parental relationship quality and child outcomes across subgroups. Washington, DC. Child Trends Research Brief. [Online] Available: http://www.childtrends.org [Accessed: 17/01/2018].

MUUSHA, 2012. Substance abuse by women and its effects on family cohesion in rural villages in the Nkonkobe municipality. Alice: University of Fort Hare. (Doctoral dissertation)

NOBLE-CARR, D., BARKER, J., McARTHUR, M., \& WOODMAN, E. 2014. Improving practice: The importance of connections in establishing positive identity and meaning in the lives of vulnerable young people. Children and Youth Services Review, 47: 389-396.

POLIT, D. F., \& BECK, C. T. 2004. Nursing research: Principles and methods $\left(7^{\text {th }}\right.$ ed). Philadelphia, PA: Lippincott Williams \& Wilkins.

PONAPPA, S., BARTLE-HARING, S., \& DAY, R. 2014. Connection to parents and healthy separation during adolescence: A longitudinal perspective. Journal of Adolescence, 37(5): 555-566.

PRIOSTE, A., NARCISO, I., GONCALVES, M. M., \& PEREIRA, C. R. 2015. Family relationships and parenting practices: A pathway to adolescents' collectivist and individualist values? Journal of Child and Family Studies, 24(11): 3258-3267.

PUTNICK, D. L., BORNSTEIN, M. H., HENDRICKS, C., PAINTER, K. M., SUWALSKY, J. T., \& COLLINS, W. A. 2008. Parenting stress, perceived parenting behaviours, and adolescent self-concept in European American families. Journal of Family Psychology, 22: 752-762.

RAPHESU, N. J. 2005.The Development of a Good Clinical Practice Training Model for use in South African Clinical Trials. Cape Town: University of Western Cape, Cape (Doctoral dissertation)

RAWATLAL, K.V., \& PETERSEN, I. 2012. Factors impeding school connectedness: A case study. South African Journal of Psychology, 42(3): 346-357.

RAWATLAL, N., PILlAY, B. J., \& KLIEWER, W. 2015. Socioeconomic status, family-related variables, and caregiver-adolescent attachment. South African Journal of Psychology, 45(4), 551563.

REPUBLIC OF SOUTH AFRICA. Child Justice Act N0. 75 of 2008. Department of Justice and Constitutional Development. Republic of South Africa. Pretoria.

RICHTER, L., \& MORELL, R. 2006. Baba: Men and fatherhood in South Africa. Cape Town, HSRC Press.

RIGGS, S.A. 2013. Adolescent Behaviour Problems and Interparental Conflict: The Moderating Role of Parent-Child Attachment. USA: Brooks/Cole.

ROSS, H., \& HOWE, N. 2009. Family influences on children's peer relationships. In: RUBIN, K.H., BUKOWSK, W.M. \& LAURSEN, E. (eds). Social, emotional, and personality development in context. Handbook of peer interactions, relationships, and groups : 508-527. New York: Guilford Press.

RUBIN, A. \& BABBIE, R. 2008. Research methods for social work $\left(6^{\text {th }}\right.$ ed $)$. Belmont, CA: Thomson Brooks/Cole. 
SAUMURE, K. \& GIVEN, L. M. 2008. Data saturation. In: GIVEN, L. M. (Ed). The SAGE Encyclopedia of Qualitative Research Methods, (1):195-196. Thousand Oaks, CA: Sage.

SCHERMERHORN, A. C., CHOW, S., \& CUMMINGS, E. M. 2010. Developmental family processes and interparental conflict: Patterns of micro level influences. Developmental Psychology, 46(4): 869885. doi:10.1037/a001966

SCHULZE, S., \& NAIDU, N. 2014. Exploring the connectedness of South African adolescents in view of cultural differences. Studies of Tribes and Tribals, 12(1): 9-18.

SENEKAL, B. 2013. Die gebruik van die netwerk teorie binne 'n sisteem teoretiese benadering tot die Afrikaans letterkunde: 'n Teorie-oorsig: Navorsing- en oorsig artikels. Tydskrif Vir Geesteswetenskappe, 53(4): 668-682.

SHANKS, T. R. W., \& DANZIGER, S. K. 2011. Poverty is acknowledged as a risk factor for many problems experienced by children and youth. Evidence from various disciplines indicates that child. Social Policy for Children and Families: A Risk and Resilience Perspective, 25(2): 5-19.

SHEHATA, A. G., \& RAMADAN, F. H. 2010. Patterns of relationship and daily interaction between parents and adolescents. Journal of American Science, 6(9): 644-655.

SKRZYPIEC, G. 2013.Adolescents' beliefs about why young people commit crime. Australian Journal of Guidance \& Counselling, 23(2): 185-200.

SOLOSKI, K. L., \& BERRYHILL, M. B. (2016). Gender differences: Emotional distress as an indirect effect between family cohesion and adolescent alcohol use. Journal of Child and Family Studies, 25(4), 1269-1283.

STANGER. C., DUMENCI, L., KAMON, J., \& BURSTEIN, M. 2004. Parenting and children's externalizing problems in substance-abusing families. Journal of Clinical Child and Adolescent Psychology, 33(3): 590-600.

STATISTIC SOUTH AFRICA. 2012. Statistical release P0318. General household survey.

STODDARD, S. A., MCMORRIS, B. J., \& SIEVINIG, R. E. 2011. Do social connections and hope matter in predicting early adolescent violence? American Journal of Community Psychology, 48(34): 247-256.

STODDARD, S., WHITESIDE, L., ZIMMERMAN, M., CUNNINGHAM, R., CHERMACK, S., \& WALTON, M. 2013. The relationship between cumulative risk and promotive factors and violent behaviour among urban adolescents. American Journal of Community Psychology, 51(1): 57-65. doi:10.1007/s10464-012-9541-7

SUKYIRUN, P. 2016. Biosocial interaction and juvenile delinquency behaviours of Thai juvenile delinquents. International Journal of Criminal Justice Sciences, 11(2): 110-113.

SYCE, S. C. 2016. Exploring caregiver-child communication about risky sexual behaviour in Cape Town. Cape Town: University of the Western Cape. (Master's thesis)

UNICEF. 2008. The state of Africa's children, 2008: Child survival. [Online] Available: https://www.unicef.org/publications/index 44410.html [Accessed: 25/03/2015].

VAN WYK, B. 2012. Research design and methods part I. University of Western Cape. [Online] Available: https://www.uwc.ac.za/Students/Postgraduate/Documents/ Research and Design 1pdf [Accessed: 9/10/2017].

VISSER, M. (ed). 2007. Contextualizing community psychology in South Africa. Pretoria: Van Schaik. 
VITULANO, M. L., FITE, P. J., \& RATHERT, J. L. 2010. Delinquent peer influence on childhood delinquency: The moderating effect of impulsivity. Journal of Psychopathology and Behavioral Assessment, 32(3): 315-322.

VON BERTALANFFY, L. 1969. General system theory: Foundations, development, applications (revised ed). New York: George Braziller.

WARD, C., MAKUSHA, T., \& BRAY, R. 2015. Parenting, poverty and young people in South Africa: What are the connections? South African child gauge: 69-74.

WENG, X., RAN, M., \& CHUI, W. H. 2016. Juvenile delinquency in Chinese adolescents: An ecological review of the literature. Aggression and Violent Behaviour, 31: 26-36.

WITTENBERG, M. 2009. The intra-household allocation of work and leisure in South Africa. Social Indicators Research, 93(1): 159-164. doi:10.1007/s11205-008-9386-5

YOUNG, T., FITZGIBBON, W., \& SILVERSTONE, D. 2013. The role of the family in facilitating gang membership, criminality and exit. A report prepared for Catch22-Dawes Unit. London: London Metropolitan University. 